\title{
MAPS SHOWING DISTRIBUTION, COMPOSITION, AND AGE OF EARLY AND MIDDLE CENOZOIC VOLCANIC CENTERS IN IDAHO, MONTANA, WEST-CENTRAL SOUTH DAKOTA, AND WYOMING
}

\author{
By Robert G. Luedke
}

\section{DISCUSSION}

This map is the third of a series showing the distribution, composition, and age of early and middle Cenozoic volcanic centers in the western conterminous United States. The maps are designed primarily as a data base of igneous systems, a major geologic environment known to promote and host mineral deposits. The data shown provide the basic information necessary for derivative studies such as the development of geologic concepts to identify and assess igneous-related mineral deposits and(or) mineralized systems. In addition, this map series shows the temporal and spatial relationships of early and middle Cenozoic igneous rocks and their geochemical and age associations, at a single common scale, within the many different igneous centers in the western states. This map series can also be used as a base for studies of volcanology, volcanotectonics, and the general geology of volcanic and related rocks. Original sources were consulted wherever possible in construction of these maps, but in areas of meager data I interpreted the general composition and age of the igneous rocks. This procedure was necessary in order to resolve internal problems and to maintain a standard treatment for meaningful comparison of data throughout the map series.

In this map series the early and middle Cenozoic time frame extends from about $58 \mathrm{Ma}$ to $16 \mathrm{Ma} ; 16 \mathrm{Ma}$ is the maximum age cutoff for a published map series designed as a guide for the evaluation of igneous-related geothermal resources (for the comparable Idaho, Montana, Wyoming, and western South Dakota region, see Luedke and Smith, 1983). Within this early and middle Cenozoic time frame, the ages of the volcanic rocks are arbitrarily divided into three time increments: 58-37 Ma, 37-24 Ma, and 24-16 Ma. The ages of 58, 37, and $24 \mathrm{Ma}$, respectively, represent the approximate Paleocene-Eocene, Eocene-Oligocene, and Oligocene-Miocene boundaries (Berggren and others, 1985).

Igneous rocks of the early and middle Cenozoic time frame are principally related to volcanotectonic activity occurring within this time span. This map, however, comprising the northern Rockies is dominated by rock masses of early Cenozoic age, and by units of sub-volcanic or intrusive rather than volcanic origin, particularly in Idaho. In comparison, the maps encompassing the middle and southern Rockies (Luedke, 1993 and in press) show a larger percentage of volcanic rocks progressively southward and are more inclusive and representative of early and middle Cenozoic times. Most volcanic rock units shown on the maps generally fit well within the selected time intervals. Locally, a few rock units that are at or within about a million years of a time boundary (particularly the 24-Ma boundary) were included with the domi- nant younger or older unit of the region in order to maintain geologic, petrologic, and tectonic continuity. Areas in eastern Arizona and western New Mexico (Luedke, 1993) and southwestern Utah (Luedke, in press) necessitated such unit assignments. Perhaps of significance is the fact that no rocks with ages in the youngest time interval (Miocene) occur in the region encompassed by this map except for a minette dike (22 Ma) in the Wind River basin about $40 \mathrm{~km}$ northwest of Lander, Wyo. Local extrusive masses of dominantly mafic composition and radiometric ages of 16-17 Ma crop out in western Idaho, but these rocks are related to and a part of the extensive volcanic fields in neighboring Oregon and Washington and were included on the late Cenozoic maps (Luedke and Smith, 1982, 1983, and 1984). A specific rock unit or volcanic field may have some ages that appear inconsistent with the majority of ages shown, e.g., the Absaroka Range in northwestern Wyoming where the dominant time interval (Eocene) was assigned. The few younger ages shown are for intrusives within the Absaroka field and probably reflect slightly younger intrusive activity or localized mineralization and alteration. All known ages for a specific unit within the 58-16 Ma time frame are shown.

Some Laramide magmatic and tectonic events that started in the Late Cretaceous or Paleocene continued into middle Eocene time (Mutschler and others, 1987), or served as precursors to similar events later in the Cenozoic. In regions mostly south of the area included in this map, volcanism and associated intrusions commenced in the very latest Eocene following a quiescence of volcanic activity in late Eocene time. This igneous activity continued on a major scale through the Oligocene, into the Miocene, to the onset of late Cenozoic volcanism and associated extensional tectonism characteristic of the Basin and Range province but also reflected in bordering regions (Christiansen and Lipman, 1972; Lipman and others, 1972; Christiansen, 1989). Because of the extraordinary amount of new geological, geochemical, geophysi$\mathrm{cal}$, and geochronological data released during the last two decades, reanalysis of Laramide and post-Laramide volcanotectonic events is justified. Keith and Wilt (1986) have done such a synthesis of Laramide events principally in Arizona and environs, and Mutschler and others (1987) similarly studied the effects of late Mesozoic and Cenozoic magmatism in Colorado and environs.

In order to show some continuity to earlier magmatic activity, a few areas of igneous rocks are outlined that are related to known Laramide magmatic or tectonic belts within the Rocky Mountain Cordillera, for instance those having ages spanning the $58 \mathrm{Ma}$ limit for this map series. These mostly pre- 58 Ma plutonic complexes of stocks, laccoliths, sills, and dikes, and the volcanic Adel Mountains, are located predominantly in the alkalic (high-potassium) igneous 
province of central Montana east of the Rocky Mountain front.

The volcanic rocks, and associated contemporaneous plutonic rocks, have been classified using a non-genetic system into five major types based primarily upon their known or inferred silicacontent:

1. Feldspathoidal basalts including basanite, tephrite, and other rare alkalic rocks

2. Basalt, including trachybasalt and hawaiite

3. Andesite, including trachyandesite and phonolite

4. Dacite, including rhyodacite, quartz latite, and trachyte

5. Rhyolite

This simplistic rock classification, not desirable for detailed volcanological purposes, emphasizes the dominant rock type within a given region, although in any specific area several rock types may be intermixed. This rock classification is the same as that used on the map of late Cenozoic volcanic rocks (Luedke and Smith, 1983), thereby permitting easy comparison.

Isotopically determined age data are referenced to the first or original source where possible. Potassium-argon ages have been recalculated where necessary using the conversion tables of Dalrymple (1979) prepared for the decay constants and isotopic abundances adopted by the IUGS Subcommission on Geochronology (Steiger and Jager, 1977). Multiple ages at a given locality are shown when cartographically possible. Some areas, for example, in the Challis, Great Falls, and Lewistown $1^{\circ}$ by $2^{\circ}$ quadrangles (fig. 1) have had more age determinations made than can be shown, and an arbitrary selection was made.

Cited references for geologic, age, and chemical information are indicated in figure 2. Several important general references are cited separately at the end and are not numbered chronologically.

\section{REFERENCES CITED}

Berggren, W. A., Kent, D. V., Flynn, J. J., and Van Couvering, J. A., 1985, Cenozoic geochronology: Geological Society of America Bulletin, v. 96, no. 1, p. 1407-1418.

Christiansen, R. L., 1989, Volcanism associated with postLaramide tectonic extension in the western U.S.: New Mexico Bureau of Mines \& Mineral Resources Bulletin 131, p. 51.

Christiansen, R. L., and Lipman, P. W., 1972, Cenozoic volcanism and plate-tectonic evolution of the western United States. II. Late Cenozoic: Royal Society [London] Philosophical Transactions, ser. A, v. 271, no. 1213, p. 249-284.

Dalrymple, G. B., 1979, Critical table for conversion of K-Ar ages from old to new constants: Geology, v. 7, no. 11, p. 558-560.

Keith, S. B., and Wilt, J. C., 1986, Laramide orogeny in Arizona and adjacent regions-a strato-tectonic synthesis, in Beatty, Barbara, and Wilkinson, P. A. K., eds., Frontiers in geology and ore deposits of Arizona and the southwest: Arizona Geological Society Digest, v. 16, p. 502-554.

Lipman, P. W., Prostka, H. J., and Christiansen, R. L., 1972, Cenozoic volcanism and plate-tectonic evolution of the west- ern United States. I. Early and Middle Cenozoic: Royal Society [London] Philosophical Transactions, ser. A, v. 271, no. 1213 , p. 217-248.

Luedke, R. G., 1993, Map showing distribution, composition, and age of early and middle Cenozoic volcanic centers in Arizona, New Mexico, and west Texas: U.S. Geological Survey Miscellaneous Investigations Series Map I-2291-A, 16 p.

- (in press), Map showing distribution, composition, and age of early and middle Cenozoic volcanic centers in Colorado and Utah: U.S. Geological Survey Miscellaneous Investigations Series Map I-2291-B, 13 p.

Luedke, R. G., and Smith, R. L., 1982, Map showing distribution, composition, and age of late Cenozoic volcanic centers in Oregon and Washington: U.S. Geological Survey Miscellaneous Investigations Series Map I-1091-D.

1983, Map showing distribution, composition, and age of late Cenozoic volcanic centers in Idaho, western Montana, west-central South Dakota, and northwestern Wyoming: U.S. Geological Survey Miscellaneous Investigations Series Map I-1091-E.

1984, Map showing distribution, composition, and age of late Cenozoic volcanic centers in the western conterminous United States: U.S. Geological Survey Miscellaneous Investigations Series Map I-1523.

Mutschler, F. E., Larson, E. E., and Bruce, R. M., 1987 (1988), Laramide and younger magmatism in Colorado-New petrologic and tectonic variations on old themes: Colorado School of Mines Quarterly, v. 82, no. 4, p. 1-47.

Steiger, R. H., and Jager, E., 1977, Subcommission on geochronology-Convention on the use of decay constants in geoand cosmochronology: Earth and Planetary Science Letters, v. 36 , no. 3 , p. $359-362$.

\section{SOURCE REFERENCES}

[Keyed to figure 2]

1. Aadland, R. K., and Bennett, E. H., 1979, Geologic map of the Sandpoint quadrangle, Idaho and Washington: Idaho Bureau of Mines and Geology Geologic Map Series, scale 1:250,000.

2. Alt, David, and Hyndman, D. W., 1980, Preliminary geologic map of the Dillon $1^{\circ} \times 2^{\circ}$ quadrangle, Montana: Montana Bureau of Mines and Geology OpenFile Report 52.

3. Alverson, D. C., 1965, Geology and hydrology of the Fort Belknap Indian Reservation, Montana: U.S. Geological Survey Water-Supply Paper 1576-F, 59 p.

4. Anderson, A. L., 1956, Geology and mineral resources of the Salmon quadrangle, Lemhi County, Idaho: Idaho Bureau of Mines and Geology Pamphlet No. 106, $102 \mathrm{p}$.

5. 1957, Geology and mineral resources of the Baker quadrangle, Lemhi County, Idaho: Idaho Bureau of Mines and Geology Pamphlet No. 112, $71 \mathrm{p}$.

6. 1959, Geology and mineral resources of the North Fork quadrangle, Lemhi County, Idaho: Idaho Bureau of Mines and Geology Pamphlet No. 118, $92 \mathrm{p}$. 
7. 1961, Geology and mineral resources of the Lemhi quadrangle, Lemhi County, Idaho: Idaho Bureau of Mines and Geology Pamphlet No. 124, $111 \mathrm{p}$.

**8. Armstrong, R. L., 1974, Geochronometry of the Eocene volcanic-plutonic episode in Idaho: Northwest Geology, v. 3, p. 1-15. [K-Ar, Rb-Sr]

**9. 1975, The geochronometry of Idaho: Isochron/ West, no. 14, p. 1-50. [K-Ar, $\mathrm{Pb}-\alpha$ ]

**10. 1976, The geochronometry of Idaho: IsochronWest, no. 15 , p. 1-34. [K-Ar]

**11. Armstrong, R. L., Harakal, J. E., and Hollister, V. F., 1982, Eocene mineralization at Mount Tolman (Keller), Washington, and Silver Dyke, Montana: Isochron/West, no. 33, p. 9-10. [K-Ar]

**12. Armstrong, R. L., Hollister, V. F., and Harakal, J. E., 1979, K-Ar dates for mineralization in the White Cloud-Cannivan porphyry molybdenum belt in Idaho and Montana-A reply: Economic Geology, v. 74, no. 3, p. 699-700. [K-Ar]

13. Armstrong, R. L., Smith, J. F., Jr., Covington, H. R., and Williams, P. L., 1978, Preliminary geologic map of the west half of the Pocatello $1^{\circ} \times 2^{\circ}$ quadrangle, Idaho: U.S. Geological Survey Open-File Report 78-533.

**14. Armstrong, R. L., Speed, R. C., Graustein, W. C., and Young, A. Y., 1976, K-Ar dates from Arizona, Montana, Nevada, Utah, and Wyoming: Isochron/West, no. 16, p. 1-6. [K-Ar]

**15. Axelrod, D. I., 1966, Potassium-argon ages of some western Tertiary floras: American Journal of Science, v. 264 , no. 7 , p. $497-506$. [K-Ar]

**16. Baadsgaard, H., Folinsbee, R. E., and Lipson, J., 1961, Potassium-argon dates of biotites from Cordilleran granites: Geological Society of America Bulletin, v. 72 , no. 5 , p. 689- 702. [K-Ar]

17. Barnett, V. H., 1917, Geology of the Hound Creek district of the Great Falls coal field, Cascade County, Montana: U.S. Geological Survey Bulletin 641-H, p. 215-232.

**18. Bassett, W. A., 1961, Potassium-argon age of Devils Tower, Wyoming: Science, v. 134, no. 3487, p. 1373. [K-Ar]

19. Batchelder, J. N., and Hall, W. E., 1978, Preliminary geologic map of the Hailey 71/2-minute quadrangle, Idaho: U.S. Geological Survey Open-File Report 78-546.

**20. Beall, J. J., 1973, Mechanics of intrusion and petrochemical evolution of the Adel Mountain volcanics: Unpublished Ph.D. dissertation, University of Montana, Missoula, 104 p. [C]

21. Becraft, G. E., Pinckney, D. M., and Rosenblum, Sam, 1963, Geology and mineral deposits of the Jefferson City quadrangle, Jefferson and Lewis and Clark Counties, Montana: U.S. Geological Survey Professional Paper 428, $101 \mathrm{p}$.

**22. Bellon, Hervé, Houlgatte, Erik, Gouronnec, Philippe, Blanchet, René, Tardy, Marc, de La Tour DuPin, Henri, Le Vot, Michel, et Villien, Alain, 1989, Le magmatisme mésozoïque et cénozoïque de l'Overthrust Belt (Cordillères nord-américaines, EtatsUnis). Ages ${ }^{40} \mathrm{~K}-{ }^{40} \mathrm{Ar}$ et signification géodynamique:
Bulletin de la Société Géologique de France, série 8, t. V, no. 3, p. 627-637. [Ar-Ar]

23. Bennett. E. H., 1977, Reconnaissance geology and geochemistry of the Blackbird Mountain-Panther Creek region, Lemhi County, Idaho: Idaho Bureau of Mines and Geology Pamphlet No. 167, 107 p.

*24. _- 1980, Reconnaissance geology and geochemistry of the Trinity Mountain-Steel Mountain area, Elmore County, Idaho: Idaho Bureau of Mines and Geology Technical Report 80-11, 56 p. [K-Ar]

**25. Bennett, E. H., and Knowles, C. R., 1985, Tertiary plutons and related rocks, in central Idaho, in McIntyre, D. H., ed., Symposium on the geology and mineral deposits of the Challis $1^{\circ} \times 2^{\circ}$ quadrangle, Idaho: U.S. Geological Survey Bulletin 1658, p. 81-95. [C]

26. Berg, R. B., 1973, Geology of southernmost Ravalli County, Montana: Northwest Geology, v. 2, part C, p. 1-5.

27. Berg, R. B., and Robocker, J. E., 1984a, Reconnaissance geologic map of the Monarch quadrangle: Montana Bureau of Mines and Geology Open-File Report MBMG-146, scale 1:24,000.

28. - 1984b, Reconnaissance geologic map of the Monarch NE quadrangle: Montana Bureau of Mines and Geology Open-File Report MBMG-145, scale $1: 24,000$.

29. 1984c, Reconnaissance geologic map of the Riceville quadrangle: Montana Bureau of Mines and Geology Open- File Report MBMG-144, scale $1: 24,000$.

30. 1984d, Reconnaissance geologic map of the Thunder Mountain quadrangle: Montana Bureau of Mines and Geology Open- File Report MBMG-147, scale 1:24,000.

31. Bergantino, R. N., 1980, Preliminary geologic map of the Forsyth $1^{\circ} \times 2^{\circ}$ quadrangle, Montana: Montana Bureau of Mines and Geology Open-File Report 48.

**32. Blackwell, D. D., Brott, C. A., Goforth, T. T., Holdaway, M. J., Morgan, Paul, Petefish, David, Rape, Thomas, Steele, J. L., Spafford, R. E., and Waibel, A. F., 1975, A brief description of the Marysville Geothermal Area, in Energy resources of Montana: Montana Geological Society 22d Annual Publication [Guidebook], p. 217222. [K-Ar]

33. Bond, J. G., 1978, Geologic map of Idaho: Idaho Bureau of Mines and Geology, scale 1:500,000.

34. Bowen, C. F., 1919, Anticlines in a part of the Musselshell Valley, Musselshell, Meagher, and Sweetgrass Counties, Montana, in Contributions to economic geology. Part II. Mineral fuels: U.S. Geological Survey Bulletin 691-F, p. 185-209.

**35. Bown, T. M., 1982, Geology, paleontology, and correlation of Eocene volcaniclastic rocks, southeast Absaroka Range, Hot Springs County, Wyoming: U.S. Geological Survey Professional Paper 1201-A, 75 p. [K-Ar]

36. Brumbaugh, D. S., and Hendrix, T. E., 1981, The McCarthy Mountain structural salient, southwestern Montana, in Tucker, T. E., and others, eds., Symposium on Southwest Montana: Montana Geological Society Field Conference Guidebook, p. 201-209. 
**37. Buie, B. F., 1941, Igneous rocks of the Highwood Mountains, Montana. Part III. Dikes and related intrusives: Geological Society of America Bulletin, v. 52, no. 11, p. 1753- 1808. [C]

**38. Burgess, C. H., 1941, Igneous rocks of the Highwood Mountains, Montana. Part IV. The stocks: Geological Society of America Bulletin, v. 52, no. 11, p. 1809 1828. [C]

39. Calvert, W. R., 1917, Geology of the upper Stillwater Basin, Stillwater and Carbon Counties, Montana, with special reference to coal and oil: U.S. Geological Survey Bulletin 641- G, p. 199-214.

*40. Cater, F. W., Pinckney, D. M., Hamilton, W. B., Parker, R. L., Weldin, R. D., Close, T. J., and Zilka, N. T., 1973, Mineral resources of the Idaho Primitive Area and vicinity, Idaho, with a section on the Thunder Mountains district, by B. F. Leonard, and a section on Aeromagnetic interpretation, by W. E. Davis: U.S. Geological Survey Bulletin 1304, 431 p. [K-Ar]

**41. Chadwick, R. A., 1968, Two Eocene volcanic episodes, Gallatin Range, Montana, in Abstracts for 1967: Geological Society of America Special Paper 115, p. 411412. [K-Ar]

*42. - 1969, The northern Gallatin Range, MontanaNorthwestern part of the Absaroka-Gallatin volcanic field: University of Wyoming, Contributions to Geology, v. 8 , no. 2 , part 2 , p. $150-166$. [K-Ar]

**43. 1970, Belts of eruptive centers in the AbsarokaGallatin volcanic province, Wyoming-Montana: Geological Society of America Bulletin, v. 81, no. 1, p. 267-273. [K-Ar; C]

**44. 1978, Geochronology of post-Eocene rhyolitic and basaltic volcanism in southwestern Montana: Isochron/West, no. 22, p. 25-28. [K-Ar]

**45. 1980, Radiometric ages of some Eocene volcanic rocks, southwestern Montana: Isochron/West, no. 27, p. 11. [K- Ar]

**46. Chase, G. H., 1972, Potassium-argon ages from wholerock analyses of igneous rocks in the area of the National Reactor Testing Station, Idaho, in Geological Survey Research 1972: U.S. Geological Survey Professional Paper 800-D, p. 123-126. [K- Ar]

47. Christiansen, R. L., Blank, H. R., Jr., Love, J. D., and Reed, J. C., Jr., 1978, Geologic map of the Grassy Lake Reservoir quadrangle, Yellowstone National Park and vicinity, Wyoming: U.S. Geological Survey Geologic Quadrangle Map GQ- 1459.

*48. Clabaugh, S. E., 1952, Corundum deposits of Montana: U.S. Geological Survey Bulletin 983, 100 p. [C]

49. Connor, J. J., and Evans, K. V., 1986, Geologic map of the Leesburg quadrangle, Lemhi County, Idaho: U.S. Geological Survey Miscellaneous Field Studies Map MF- 1880.

**50. Criss, R. E., and Fleck, R. J., 1987, Petrogenesis, geochronology, and hydrothermal systems of the northern Idaho Batholith and adjacent areas based on ${ }^{18} \mathrm{O} /{ }^{16} \mathrm{O}, \mathrm{D} / \mathrm{H},{ }^{87} \mathrm{Sr} /{ }^{86} \mathrm{Sr}, \mathrm{K} / \mathrm{Ar}$, and ${ }^{40} \mathrm{Ar} /{ }^{39} \mathrm{Ar}$ studies, in Vallier, T. L., and Brooks, H. C., eds., Geology of the Blue Mountains region of Oregon, Idaho, and Washington: U.S. Geological Survey Professional Paper 1436, p. 95-137. [K-Ar, Ar-Ar; C]
**51. Dahy, J. P., 1991, Geology and igneous rocks of the Yogo sapphire deposit, in Baker, D. W., and Berg, R. B., eds., Guidebook of the central Montana alkalic province: Montana Bureau of Mines and Geology Special Publication 100, p. 45-54. [C]

**52. Daniel, Faith, and Berg, R. B., 1981, Radiometric dates of rocks in Montana: Montana Bureau of Mines and Geology Bulletin no. 114, 136 p. [K-Ar, FT]

*53. Darton, N. H., 1905, Description of the Sundance quadrangle [Wyoming-South Dakota]: U.S. Geological Survey Geologic Atlas, Folio No. 127, 12 p. [C]

54. 1909, Geology and water resources of the northern Black Hills and adjoining regions in South Dakota and Wyoming: U.S. Geological Survey Professional Paper 65, $105 \mathrm{p}$

55. _ 1951, Geologic map of South Dakota: U.S. Geological Survey, scale 1:500,000.

56. Darton, N. H., and O'Harra, C. C., 1905, Description of the Aladdin quadrangle [Wyoming-South Dakota]: U.S. Geological Survey Geologic Atlas, Folio No. 128, $8 \mathrm{p}$.

*57. 1907, Description of the Devil's Tower quadrangle [Wyoming]: U.S. Geological Survey Geologic Atlas, Folio No. 150,10 p. [C]

*58. Darton, N. H., and Paige, Sidney, 1925, Description of the central Black Hills [South Dakota]: U.S. Geological Survey Atlas, Folio No. 219, 34 p. [C]

59. DeWitt, Ed, Redden, J. A., Buscher, David, and Wilson, Anna Burack, 1989, Geologic map of the Black Hills area, South Dakota and Wyoming: U.S. Geological Survey Miscellaneous Investigations Series Map I-1910.

60. DeWitt, Ed, Redden, J. A., Wilson, Anna Burack, and Buscher, David, 1986, Mineral resource potential and geology of the Black Hills National Forest, South Dakota and Wyoming, with a section on Salable commodities, by J. S. Dersch: U.S. Geological Survey Bulletin 1580, 135 p.

**61. Dover, J. H., 1981, Geology of the Boulder-Pioneer Wilderness Study Area, Blaine and Custer Counties, Idaho: U.S. Geological Survey Bulletin 1497-A, 75 p. [K-Ar, Rb-Sr]

62. - 1983, Geologic map and sections of the central Pioneer Mountains, Blaine and Custer Counties, central Idaho: U.S. Geological Survey Miscellaneous Investigations Series Map I-1319.

63. Dover, J. H., Hall, W. E., Hobbs, S. W., Tschanz, C. M., Batchelder, J. N., and Simons, F. S., 1976, Geologic map of the Pioneer Mountains region, Blaine and Custer Counties, Idaho: U.S. Geological Survey Open-File Report OF 76-75.

**64. Dudás, F. O., 1990, Petrogenesis and mantle source of igneous rocks in the Crazy Mountains, Montana: Unpublished Ph.D. dissertation, The Pennsylvania State University, University Park, 442 p. [C]

**65. 1991, Geochemistry of igneous rocks from the Crazy Mountains, Montana, and tectonic models for the Montana alkalic province: Journal of Geophysical Research, v. 96, no. B8, p. 13,261-13,277. [Rb-Sr]

**66. Dudás, F. O., Carlson, R. W., and Eggler, D. H., 1987, Regional Middle Proterozoic enrichment of the sub- 
continental mantle source of igneous rocks from central Montana: Geology, v. 15, no. 1, p. 22-25. [Rb-Sr]

67. Egbert, R. L., 1967, Geologic map of the Madison Valley- Hebgen Lake, southwestern Montana: Montana Geological Society 18th Annual Field Conference Guidebook, scale 1:250,000.

**68. Ekren, E. B., 1985, Eocene cauldron-related volcanic events in the Challis quadrangle, in Mclntyre, D. H., ed., Symposium on the geology and mineral deposits of the Challis $1^{\circ} \times 2^{\circ}$ quadrangle, Idaho: U.S. Geological Survey Bulletin 1658, p. 43-58. [C]

*69. Ekren, E. B., Mclntyre, D. H., and Bennett, E. H., 1984, High-temperature, large-volume, lavalike ash-flow tuffs without calderas in southwestern Idaho: U.S. Geological Survey Professional Paper 1271, 76 p. [C]

*70. Ekren, E. B., McIntyre, D. H., Bennett, E. H., and Malde, E. H., 1981, Geologic map of Owyhee County, Idaho, west of longitude $116^{\circ}$ W.: U.S. Geological Survey Miscellaneous Investigations Series Map I-1256. [K-Ar]

*71. Elliott, J. E., 1979, Geologic map of the southwest part of the Cooke City quadrangle, Montana and Wyoming: U.S. Geological Survey Miscellaneous Investigations Series Map I- 1084. [K-Ar, FT]

72. Elliott, J. E., Gaskill, D. L., and Raymond, W. H., 1983, Geological and geochemical investigations of the North Absaroka Wilderness Study Area, Park and Sweet Grass Counties, Montana, in Mineral resources of the North Absaroka Wilderness Study Area, Park and Sweet Grass Counties, Montana: U.S. Geological Survey Bulletin 1505, p. 5-103.

73. Elliott. J. E., Wallace, C. A., O'Neill, J. M., Hanna, W. F., Rowan, L. C., Zimbelman, D. R., Pearson, R. C., Close, T. J., Federspiel, F. E., Causey, J. D., Willett, S. L., Morris, R. W., and Huffsmith, J. R., 1985, Mineral resource potential of the Anaconda-Pintlar Wilderness Area, Granite, Deerlodge, Beaverhead, and Ravalli Counties, Montana: U.S. Geological Survey Miscellaneous Field Studies Map MF-1633-A.

**74. Emmons, W. H., 1908, Geology of the Haystack stock, Cowles, Park County, Montana: Journal of Geology, v. 16 , no. 3, p. 193-229. [C]

**75. Faul, Henry, 1960, Geologic time scale: Geological Society of America Bulletin, v. 71, no. 5, p. 637-644. [K-Ar]

**76. Fisher, F. S., 1981, Controls and characteristics of metallic mineral deposits in the southern Absaroka Mountains, Wyoming, in Tucker, T. E., ed., Symposium on Southwest Montana: Montana Geological Society Field Conference Guidebook, p. 343- 348. [FT]

*77. _ 1982, Porphyry copper deposits associated with the Needle Creek igneous center, southern Absaroka Mountains, Wyoming, in Symposium on the genesis of Rocky Mountain ore deposits-Changes with time and tectonics: Denver Region Exploration Geologists Society Proceedings, p. 87-93. [FT; C]

*78. Fisher, F. S., McIntyre, D. H., and Johnson, K. M., 1993, Geologic map of the Challis $1^{\circ} \times 2^{\circ}$ quadrangle, Idaho: U.S. Geological Survey Miscellaneous Investigations Series Map I-1819, 39 p. [K-Ar, Ar-Ar]
79. Fisk, H. G., 1969, Painted Rocks Lake area, southern Ravalli County, Montana: Montana Bureau of Mines and Geology Special Publication 47 (map-scale 1:49,000).

80. Foose, R. M., Wise, D. U., and Garbarini, G. S., 1961, Structural geology of the Beartooth Mountains, Montana and Wyoming: Geological Society of America Bulletin, v. 72, no. 8, p. 1143-1172.

81. Fraser, G. D., and Waldrop, H. A., 1972, Geologic map of the Wise River quadrangle, Silver Bow-Beaverhead Counties, Montana: U.S. Geological Survey Geologic Quadrangle Map GQ-988.

82. Fraser, G. D., Waldrop, H. A., and Hyden, H. J., 1969, Geology of the Gardiner area, Park County, Montana: U.S. Geological Survey Bulletin 1277, 118 p.

83. Freeman, V. L., 1977, Reconnaissance geologic map of the Hamen quadrangle, Meagher County, Montana: U.S. Geological Survey Open-File Report 77-137.

84. Frost, T. P., 1992, Written communication.

85. Gardner, L. S., 1950, Geology of the Button ButteForestgrove area, Fergus County, Montana: U.S. Geological Survey Oil and Gas Investigations Preliminary Map 106.

86. Goddard, E. N., 1988, Geologic map of the Judith Mountains, Fergus County, Montana: U.S. Geological Survey Miscellaneous Investigations Series Map I-1729.

**87. Greenwood, W. R., and Morrison, D. A., 1973, Reconnaissance geology of the Selway-Bitterroot Wilderness Area: Idaho Bureau of Mines and Geology Pamphlet No. 154,30 p. [K-Ar]

88. Griggs, A. B., 1973, Geologic map of the Spokane quadrangle, Washington, Idaho, and Montana: U.S. Geological Survey Miscellaneous Investigations Series Map I-768.

89. Groff, S. L., 1965, Reconnaissance ground-water and geological studies, western Meagher County, Montana: Montana Bureau of Mines and Geology Special Publication 35, $23 \mathrm{p}$.

90. Gualtieri, J. L., 1975, Preliminary unedited geologic map of the Confederate Gulch area, Broadwater and Meagher Counties, Montana: U.S. Geological Survey Open-File Report OF-75-211.

91. Hadley, J. B., 1969a, Geologic map of the Cameron quadrangle, Madison County, Montana: U.S. Geological Survey Geologic Quadrangle Map GQ-813.

92. __ 1969b, Geologic map of the Varney quadrangle, Madison County, Montana: U.S. Geological Survey Geologic Quadrangle Map GQ-814.

93. Hamilton, Warren, 1963, Petrology of rhyolite and basalt, northwestern Yellowstone Plateau, in Geological Survey Research 1963: U.S. Geologiral Survey Professional Paper 475-C, p. C78- C81.

**94. Hardyman, R. F., 1985, The Twin Peaks caldera and associated ore deposits, in McIntyre, D. H., ed., Symposium on the geology and mineral deposits of the Challis $1^{\circ} \times 2^{\circ}$ quadrangle, Idaho: U.S. Geological Survey Bulletin 1658, p. 97- 105. [C]

**95. Hardyman, R. F., and Fisher, F. S., 1985, Rhyolite intrusions and associated mineral deposits in the Challis volcanic field, Challis quadrangle, in McIntyre, D. H., ed., Symposium on the geology and mineral deposits 
of the Challis $1^{\circ} \times 2^{\circ}$ quadrangle, Idaho: U.S. Geological Survey Bulletin 1658, p. 167- 179. [C]

**96. Harlan, S. S., and Lageson, D. R., 1983, Timing of deformation along the leading edge of the fold and thrust belt, Crazy Mountains Basin, Montana: Isochron/West, no. 36, p. 7-8. [K-Ar]

**97. Harlan, S. S., Geissman, J. W., Lageson, D. R., and Snee, L. W., 1988, Paleomagnetic and isotopic dating of thrust-belt deformation along the eastern edge of the Helena salient, northern Crazy Mountains Basin, Montana: Geological Society of America Bulletin, v. 100 , no. 4 , p. $492-499$. [K-Ar]

**98. Harlan, S. S., Mehnert, H. H., Snee, L. W., and Meen, J. $\mathrm{K}$, 1991, Preliminary isotopic (K-Ar and ${ }^{40} \mathrm{Ar} /{ }^{39} \mathrm{Ar}$ ) age determinations from selected Late Cretaceous and Tertiary igneous rocks in Montana, in Baker, D. W., and Berg, R. B., eds., Guidebook of the central Montana alkalic province: Montana Bureau of Mines and Geology Special Publication 100, p. 136-137. [K-Ar]

99. Harrison, J. E., Griggs, A. B., and Wells, J. D., 1986, Geologic and structure maps of the Wallace $1^{\circ} \times 2^{\circ}$ quadrangle, Montana and Idaho: U.S. Geological Survey Miscellaneous Investigations Series Map I-1509-A.

*100. Harrison, J. E., Kleinkopf, M. D., and Obradovich, J. D., 1972, Tectonic events at the intersection between the Hope fault and the Purcell Trench, northern Idaho: U.S. Geological Survey Professional Paper 719, 24 p. [K-Ar; C]

**101. Hart, W. K., and Carlson, R. W., 1985, Distribution and geochronology of Steens Mountain-type basalts from the northwestern Great Basin: Isochron/West, no. 43, p. 5- 10. [K- Ar]

102. Hearn, B. C., Jr., 1976, Geologic and tectonic maps of the Bearpaw Mountains area, north-central Montana: U.S. Geological Survey Miscellaneous Investigations Series Map I-919.

103. _ 1979, Preliminary map of diatremes and alkalic ultramafic intrusions in the Missouri River Breaks and vicinity, north-central Montana: U.S. Geological Survey Open-File Report 79-1128.

**104. 1989a, Alkalic ultramafic magmas in north-central Montana, USA: Genetic connections of alnöite, kimberlite, and carbonatite, in Jaques, A. L., Ferguson, J., and Green D. H., eds., Kimberlites and related rocks. Volume I. Their composition, occurrence, origin and emplacement: Geological Society of Australia Special Publication no. 14, p. 109-119. [C]

**105. 1989b, The Montana high-potassium igneous province, in Volcanism and plutonism of western North America, Vol. 2: 28th International Geological Congress Field Trip Guide T346, American Geophysical Union, Washington, D.C., 86 p. [C]

**106. 1992, Oral and written communications. [K-Ar; C]

**107. Hearn, B. C., Jr., Pecora, W. T., and Swadley, W. C., 1964, Geology of the Rattlesnake quadrangle, Bearpaw Mountains, Blaine County, Montana: U.S. Geological Survey Bulletin 1181-B, 66 p. [C]

108. Hietanen, Anna, 1962, Metasomatic metamorphism in western Clearwater County, Idaho: U.S. Geological Survey Professional Paper 344-A, 116 p.
109. - 1963a, Anorthosite and associated rocks in Boehls Butte quadrangle and vicinity, Idaho: U.S. Geological Survey Professional Paper 344-B, 78 p.

*110. 1963b, Idaho batholith near Pierce and Bungalow, Clearwater County, Idaho: U.S. Geological Survey Professional Paper 344-D, 42 p. [C]

111. - 1963c, Metamorphism of the Belt Series in the Elk River-Clarkia area, Idaho: U.S. Geological Survey Professional Paper 344-C, 49 p.

*112. 1968, Belt Series in the region around Snow Peak and Mallard Peak, Idaho: U.S. Geological Survey Professional Paper 344-E, 34 p. [C]

**113. - 1969, Distribution of Fe and Mg between garnet, staurolite, and biotite in aluminum-rich schist in various metamorphic zones north of the Idaho batholith: American Journal of Science, v. 267, no. 3, p. 422456. [K-Ar]

**114. Hill, D. J., Izett, G. A., and Naeser, C. W., 1975, Early Tertiary fission track ages of sphene from Devils Tower and Missouri Buttes, Black Hills, northeastern Wyoming: Geological Society of America Abstracts with Programs, v. 7, no. 5, p. 613-614. [FT]

115. Hirsch, T. L., and Hyndman, D. W., 1985, Evolution of Square Butte laccolith, eastern Highwood Mountains, Montana: Northwest Geology, v. 14, p. 17-31.

**116. Hughes, G. J., Jr., 1971, Petrology and tectonic setting of igneous rocks in the Henderson-Willow Creek igneous belt, Granite County, Montana: Unpublished Ph.D. dissertation, Michigan Technological University, Houghton, 236 p. [K-Ar; C]

117. Huntsman, J. R., and Platt, L. B., 1985, Geologic map and cross sections of the Caribou Mountain area, southeastern Idaho: U.S. Geological Survey Miscellaneous Field Investigations Map MF-1715.

**118. Hurlbut, C. S., Jr., 1939, Igneous rocks of the Highwood Mountains, Montana, with section on Structure and mechanism of intrusion, by D. T. Griggs. Part I. The laccoliths: Geological Society of America Bulletin, v. 50, no. 7, p. 1043- 1112. [C]

119. Hyndman, D. W., and Alt, D., 1987, Radial dikes, laccoliths, and gelatin models: Journal of Geology, v. 95, no. 6, p. 763-774.

120. Iddings, J. P., and Weed, W. H., 1894, Description of the Livingston quadrangle [Montana]: U.S. Geological Survey Geologic Atlas, Folio No. 1, 4 p.

**121. Irving, J. D., 1899, A contribution to the geology of the Black Hills: Annals of the New York Academy of Sciences, v. 12 , no. 8, p. 187-340. [C]

**122. Jaffe, H. W., Gottfried, David, Waring, C. L., and Worthing, H. W., 1959, Lead-alpha age determinations of accessory minerals of igneous rocks (1953-1957): U.S. Geological Survey Bulletin 1097-B, p. 65-148. $[\mathrm{Pb}-\alpha]$

123. Jaggar, T. A., Jr., 1901, Laccoliths of the Black Hills, with a chapter on Experiments illustrating intrusion and erosion, by Ernest Howe: U.S. Geological Survey 21st Annual Report, part 3, p. 163-303.

124. Johnson, K. M., Lewis, R. S., Bennett, E. H., and Kiilsgaard, T. H., 1988, Cretaceous and Tertiary intrusive rocks of south-central Idaho, in Link, P. K., and Hack- 
ett, W. R., eds., Guidebook to the geology of central and southern Idaho: Idaho Geological Survey Bulletin 27, p. $55-86$.

125. Johnson, W. D., Jr., and Smith, H. R., 1964, Geology of the Winnett-Mosby area, Petroleum, Garfield, Rosebud, and Fergus Counties, Montana: U.S. Geological Survey Bulletin 1149, 91 p.

*126. Jones, R. W., 1982, Early Tertiary-age Kamiah Volcanics, north-central Idaho, in Bonnichsen, Bill, and Breckenridge, R. M., eds., Cenozoic geology of Idaho: Idaho Bureau of Mines and Geology Bulletin 26, p. 43- 52. [C]

127. Karasevich, L. P., Garihan, J. M., Dahl, P. S., and Okuma, A. F., 1981, Summary of Precambrian metamorphic and structural history, Ruby Range, southwest Montana, in Tucker, T. E., and others, eds., Symposium on Southwest Montana: Montana Geological Society Field Conference Guidebook, p. 225237.

128. Karner, F. R., 1981, Geologic relationships in the western centers of the northern Black Hills Cenozoic igneous province, in Rich, F. J., ed., Geology of the Black Hills, South Dakota and Wyoming: Geological Society of America Rocky Mountain Section, 1981 Annual Meeting Guidebook, American Geological Institute, p. 126-134.

129. Keefer, W. R., 1970, Structural geology of the Wind River Basin, Wyoming: U.S. Geological Survey Professional Paper 495- D, 35 p.

130. 1972, Geologic map of the west half of the Neihart 15-minute quadrangle, central Montana: U.S. Geological Survey Miscellaneous Geologic Investigations Map I-726.

131. Kemp, J. F., and Billingsley, Paul, 1921, Sweetgrass Hills, Montana: Geological Society of America Bulletin, v. 32 , no. 4 , p. 437-478.

**132. Kendrick, G. C., and Edmond, C. L., 1981, Magma immiscibility in the Shonkin Sag and Square Butte laccoliths: Geology, v. 9, no. 12, p. 615-619. [C]

**133. Kerr, J. H., Pecora, W. T., Stewart, D. B., and Dixon, H. R., 1957, Preliminary geologic map of the Shambo quadrangle, Bearpaw Mountains, Montana: U.S. Geological Survey Miscellaneous Geologic Investigations Map I-236. [C]

*134. Ketner, K. B., Keefer, W. R., Fisher, F. S., Smith, D. S., and Raabe, R. G., 1966, Mineral resources of the Stratified Primitive Area, Wyoming: U.S. Geological Survey Bulletin 1230- E, 56 p. [C]

135. Kiilsgaard, T. H., 1983, Geologic map of the Ten Mile West Roadless Area, Boise and Elmore Counties, Idaho: U.S. Geological Survey Miscellaneous Field Studies Map MF- 1500-A.

136. 1992, Written communication.

137. Kiilsgaard, T. H., Freeman, V. L., and Coffman, J. S., 1970, Mineral resources of the Sawtooth Primitive Area, Idaho: U.S. Geological Survey Bulletin 1319-D, 174 p.

**138. Kirchner, G. L., 1982, Field relations, petrology, and mineralization of the Linster Peak dome, Fergus County, Montana: Unpublished M.S. thesis, University of Montana, Missoula, 115 p. [K-Ar; C]
*139. Kirchner, J. G., 1971, The petrography and petrology of the phonolite porphyry intrusions of the northern Black Hills, South Dakota: Unpublished Ph.D. dissertation, University of lowa, lowa City, 197 p. [C]

140. Kleinkopf, M. D., and Mudge, M. R., 1972, Aeromagnetic, Bouguer gravity, and generalized geologic studies of the Great Falls-Mission Range area, northwestern Montana, in Geophysical field investigations: U.S. Geological Survey Professional Paper 726-A, p. A1-A19.

141. Kleinkopf, M. D., and Redden, J. A., 1975, Bouguer gravity, aeromagnetic, and generalized geologic map of part of the Black Hills of South Dakota and Wyoming: U.S. Geological Survey Geophysical Investigations Map GP-903.

142. Knechtel, M. M., 1959, Stratigraphy of the Little Rocky Mountains and encircling foothills, Montana: U.S. Geological Survey Bulletin 1072-N, p. 723-752.

**143. Koesterer, M. E., Bartel, A. J., Elsheimer, H. N., Baker, J. W., King, B. S., and Espos, L. F., 1982, Major element X-ray fluorescence analyses of rock samples from the Selway-Bitterroot Wilderness, Idaho County, Idaho, and Missoula and Ravalli Counties, Montana: U.S. Geological Survey Open-File Report 82- 1094, 36 p. [C]

**144. Kudo, A. M., and Broxton, D. E., 1985, High-potassium intrusive rocks of the Crandall ring-dike complex, Absaroka Mountains, Wyoming: Geological Society of America Bulletin, v. 96 , no. 4, p. 522-528. [FT; C]

**145. Kuhn, P. W., 1983, Magma immiscibility in the Box Elder laccolith of north-central Montana: Unpublished M.S. thesis, University of Montana, Missoula, 86 p. [C]

*146. Lange I. M., and Zehner, R. E., 1989, Isotope data, ages and geology of the Hog Heaven volcanic field, northwestern Montana: Isochron/West, no. 54, p. 8-10. [K-Ar]

*147. Larsen, E. S., 1941, Igneous rocks of the Highwood Mountains, Montana. Part II. The extrusive rocks: Geological Society of America Bulletin, v. 52, no. 11, p. $1733-1752$. [C]

**148. Larsen, E. S., Hurlbut, C. S., Jr., Burgess, C. H., and Buie, B. F., 1941, Igneous rocks of the Highwood Mountains, Montana. Part VII. Petrology: Geological Society of America Bulletin, v. 52, no. 12, part 1, p. 1857-1868. [C]

**149. Leonard, B. F., and Marvin, R. F., 1982, Temporal evolution of the Thunder Mountain caldera and related features, central Idaho, in Bonnichsen, Bill, and Breckenridge, R. M., eds., Cenozoic geology of Idaho: Idaho Bureau of Mines and Geology Bulletin 26, p. 23- 42. [K-Ar]

**150. Leppert, D. E., 1985, Differentiation of a shoshonitic magma at Snake Butte, Blaine County, Montana: Unpublished M.S. thesis, University of Montana, Missoula, 121 p. [C]

**151. Lewis, R. S., and Kiilsgaard, T. H., 1991, Eocene plutonic rocks in south central Idaho: Journal of Geophysical Research, v. 96, no. B8, p. 13,295-13,311. [C] 
152. Lewis, R. S., Burmester, R. F., Bennett, E. H., and White, D. L., 1990, Geologic map of the Elk City region, Idaho: Idaho Geological Survey Tecnical Report 90-2.

153. Lewis, R. S., Burmester, R. F., Reynolds, R. W., Bennett, E. H., Myers, P. E., and Reid, R. R., 1992a, Geologic map of the Lochsa River area, northern Idaho: Idaho Geological Survey Map Series, scale 1:100,000.

154. Lewis, R. S., Burmester, R. F., McFaddan, M. D., Eversmeyer, B. A., Wallace, C. A., and Bennett, E. H., 1992b, Geologic map of the upper North Fork of the Clearwater River area, northern Idaho: Idaho Geological Survey Map Series, scale 1:100,000.

*155. Lindsey. D. A., 1982, Geologic map and discussion of selected mineral resources of the North and South Moccasin Mountains, Fergus County, Montana: U.S. Geological Survey Miscellaneous Investigations Series Map I-1362, 8p. [C]

156. Lindvall, R. M., 1953, Geology of the Eagleton quadrangle, Montana: U.S. Geological Survey Geologic Quadrangle Map GQ-29.

157. __ 1956, Geology of the Big Sandy quadrangle, Montana: U.S. Geological Survey Miscellaneous Geologic Investigations Map I-130.

158. - 1962a, Geology of the Eagle Buttes quadrangle, Choteau County, Montana: U.S. Geological Survey Miscellaneous Geologic Investigations Map I-349.

159. 1962b, Geology of the Eskay quadrangle, Choteau and Blaine Counties, Montana: U.S. Geological Survey Miscellaneous Geologic Investigations Map I-353.

160. Lisenbee, A. L., and Roggenthen, W. M., 1990, Diatremes and breccia pipes of the northern Black Hills, South Dakota-Wyoming, in Paterson, C. J., and Lisenbee, A. L., eds., Metallogeny of gold in the Black Hills, South Dakota: Soceity of Economic Geologists Guidebook Series, v. 7, p. 175-181.

161. Lisenbee, Alvis, Karner, Frank, Fashbaugh, Earl, Halvorson, Don, O'Toole, Frederick, White, Stan, Wilkinson, Michael, and Kirchner, James, 1981, Geology of the Tertiary intrusive province of the northern Black Hills, South Dakota and Wyoming, in Rich, F. J., ed., Geology of the Black Hills, South Dakota and Wyoming: Geological Society of America Rocky Mountain Section, 1981 Annual Meeting Guidebook, American Geological Institute, p. 33-105.

162. Lopez, D. A., 1982a, Reconnaissance geologic map of the Gibbonsville quadrangle, Lemhi County, Idaho and Beaverhead County, Montana: U.S. Geological Survey Miscellaneous Field Studies Map MF-1446.

163. 1982b, Reconnaissance geologic map of the Ulysses Mountain quadrangle, Lemhi County, Idaho: U.S. Geological Survey Miscellaneous Field Studies Map MF- 1445.

164. Love, J. D., 1939, Geology along the southern margin of the Absaroka Range, Wyoming: Geological Society of America Special Paper no. 20, 134 p.

165. __ 1956, Geologic map of Teton County, Wyoming: Wyoming Geological Association Guidebook, 11th Annual Field Conference, 1956, Jackson Hole, scale 1:200,000.
*166. ___ 1970, Cenozoic geology of the Granite Mountains area, central Wyoming: U.S. Geological Survey Professional Paper 495-C, 154 p. [K-Ar]

167. Love, J. D., and Christiansen, A. C., 1985, Geologic map of Wyoming: U.S. Geological Survey, scale 1:500,000.

168. Love, J. D., Christiansen, A. C., and McGrew, L. W., 1978, Preliminary geologic map of the Gillette $1^{\circ} \times 2^{\circ}$ quadrangle, northeastern Wyoming and western South Dakota: U.S. Geological Survey Open-File Report 78- 343, 7 p.

169. Love, J. D., Leopold, E. B., and Love, D. M., 1978, Eocene rocks, fossils, and geologic history, Teton Range, northwestern Wyoming: U.S. Geological Survey Professional Paper 932-B, $40 \mathrm{p}$.

**170. Love, J. D., McKenna, M. C., and Dawson, M. R., 1976, Eocene, Oligocene, and Miocene rocks and vertebrate fossils at the Emerald Lake locality, 3 miles south of Yellowstone National Park, Wyoming: U.S. Geological Survey Professional Paper 932-A, 28 p. [K-Ar]

171. Love, J. D., Christiansen, A. C., Bown, T. M., and Earle, J. L., 1979, Preliminary geologic map of the Thermopolis $1^{\circ} \times 2^{\circ}$ quadrangle, central Wyoming: U.S. Geological Survey Open-File Report 79-962.

172. Love, J. D., Christiansen, A. C., Earle, J. L., and Jones, R. W., 1979, Preliminary geologic map of the Casper $1^{\circ} \times 2^{\circ}$ quadrangle, central Wyoming: U.S. Geological Survey Open- File Report 79-961, 14 p.

**173. Love, L. L., Kudo, A. M., and Love, D. M., 1976, Dacites of Bunsen Peak, the Birch Hills, and the Washakie Needles, northwestern Wyoming, and their relationship to the Absaroka volcanic field, Wyoming and Montana: Geological Society of America Bulletin, v. 87 , no. 10 , p. $1455-1462$. [K-Ar; C]

174. Lovering, T. S., 1930, The New World or Cooke City mining district, Park County, Montana, in Contributions to economic geology, 1929. Part I. Metals and nonmetals except fuels: U.S. Geological Survey Bulletin 811-A, p. 1-87.

175. Lowell, W. R., 1965, Geologic map of the BannackGrayling area, Beaverhead County, Montana: U.S. Geological Survey Miscellaneous Geologic Investigations Map I-433.

176. Lund, Karen, 1992, Written communication.

*177. Lund, Karen, Rehn, W. M., and Holloway, C. D., 1983, Geologic map of the Blue Joint Wilderness Study Area, Ravalli County, Montana, and the Blue Joint Roadless Area, Lemhi County, Idaho: U.S. Geological Survey Miscellaneous Field Studies Map MF-1557-B. [K-Ar]

178. Lund, Karen, Alminas, H. V., Kleinkopf, M. D., Ehmann, W. J., and Bliss, J.'D., 1989, Preliminary mineral resource assessment of the Elk City $1^{\circ} \times 2^{\circ}$ quadrangle, Idaho and Montana: U.S. Geological Survey Open-File Report 89-0016, 123 p.

179. Lund, Karen, Mutschler, F. M., Pawlowski, M. R., Hall, B. S., Bruce, R. M., and Evans, K. V., 1992, Geologic maps of the Big Mallard, Middle Baragamin, and Magruder Additions to the Frank Church-River-of -No-Return Wilderness, Lemhi and Idaho Counties, Idaho: U.S. Geological Survey Miscellaneous Field Studies Map MF- 2204. 
*180. Lyons, J. B., 1944, Igneous rocks of the northern Big Belt Range, Montana: Geological Society of America Bulletin, v. 55, no. 4, p. 445-472. [C]

181. Malde, H. E., Powers, H. A., and Marshall, C. H., 1963, Reconnaissance geologic map of west-central Snake River Plain, Idaho: U.S. Geological Survey Miscellaneous Geologic Investigations Map I-373.

182. Mann, J. A., 1960, Geology of part of the Gravelly Range area, Montana, in Campau, D. E., and Anisgard, H. W., eds., West Yellowstone-earthquake area: Billings Geological Society 11th Annual Field Conference Guidebook, p. 114-127.

183. Mapel, W. J., and Pillmore, C. L., 1963, Geology of the Inyan Kara Mountain quadrangle, Crook and Weston Counties, Wyoming: U.S. Geological Survey Bulletin $1121-\mathrm{M}, 56 \mathrm{p}$.

184. Mapel, W. J., and Shropshire, K. L., 1973, Preliminary geologic map and section of the Hawley Mountain quadrangle, Custer, Butte, and Lemhi Counties, Idaho: U.S. Geological Survey Miscellaneous Field Studies Map MF-546.

185. Mapel, W. J., Read, W. H., and Smith, R. K., 1965, Geologic map and sections of the Doublespring quadrangle, Custer and Lemhi Counties, Idaho: U.S. Geological Survey Geologic Quadrangle Map GQ-464.

**186. Marvin, R. F., and Dodson, S. W., 1979, Radiometric ages-Compilation B, U.S. Geological Survey: Isochron/West, no. 26, p. 3-32. [K-Ar]

**187. Marvin, R. F., Zen, E-An, and Mehnert, H. H., 1982, Tertiary volcanics along the eastern flank of the Pioneer Mountains, southwestern Montana: Isochron/ West, no. 33, p. 11- 13. [K-Ar]

**188. Marvin, R. F., Mehnert, H. H., Naeser, C. W., and Zartman, R. E., 1989a, U.S. Geological Survey radiometric ages-Compilation " $\mathrm{C}$ ". Part five-Colorado, Montana, Utah, and Wyoming: Isochron/West, no. 53, p. 14-19. [K-Ar, FT]

**189. _ 1989b, U.S. Geological Survey radiometric ages-Compilation " $\mathrm{C}$ ". Part four-Idaho, Oregon, and Washington: Isochron/West, no. 53, p. 3-13. [K-Ar, FT, Rb-Sr, Pb- $\alpha, \mathrm{Pb}-\mathrm{Th}-\mathrm{U}$ ]

**190. Marvin, R. F., Wier, K. L., Mehnert, H. H., and Menitt, V. M., 1974, K-Ar ages of selected Tertiary igneous rocks in southwestern Montana: Isochron/West, no. 10, p. 17-20. [K-Ar]

**191. Marvin, R. F., Witkind, I. J., Keefer, W. M., and Mehnert, H. H., 1973, Radiometric ages of intrusive rocks in the Little Belt Mountains, Montana: Geological Society of America Bulletin, v. 84, no. 6, p. 1977-1986. [K-Ar, $\mathrm{Rb}-\mathrm{Sr}]$

**192. Marvin, R. F., Zartman, R. E., Obradovich, J. D., and Harrison, J. E., 1984, Geochronometric and lead isotope data on samples from the Wallace $1^{\circ} \times 2^{\circ}$ quadrangle, Montana and Idaho: U.S. Geological Survey Miscellaneous Field Studies Map MF-1354- G. [K-Ar, $\mathrm{Pb}-\mathrm{U}]$

**193. Marvin, R. F., Zen, E-An, Hammarstrom, J. M, and Mehnert, H. H., 1983, Cretaceous and Paleocene potassium-argon mineral ages of the northern Pioneer batholith and nearby igneous rocks in southwest Montana: Isochron/West, no. 38, p. 11-16. [K-Ar]
**194. Marvin, R. F., Hearn, B. C., Jr., Mehnert, H. H., Naeser, C. W., Zartman, R. E., and Lindsay, D. A., 1980, Late Cretaceous-Paleocene-Eocene igneous activity in north-central Montana: Isochron/West, no. 29, p. 5-25. [K- Ar]

195. Matson, R. E., 1960, Petrography and petrology of Smoky Butte intrusives, Garfield County, Montana: U.S. Geological Survey Open-File Report No. 594, $74 \mathrm{p}$.

**196. McDowell, R. W., 1971, K-Ar ages of igneous rocks from the western United States: Isochron/West, no. 2, p. 1-16. [K- Ar]

197. McGrew, L. W., 1977a, Geologic map of the Black Butte Mountain quadrangle, Meagher County, Montana: U.S. Geological Survey Geologic Quadrangle Map GQ-1381.

198. 1977b, Geologic map of the Ringling quadrangle, Meagher County, Montana: U.S. Geological Survey Geologic Quadrangle Map GQ-1382.

**199. McIntyre, D. H., Hobbs, S. W., Marvin, R. F., and Mehnert, H. H., 1976, Late Cretaceous and Eocene ages for hydrothermal alteration and mineralization, Bayhorse district and vicinity, Custer County, Idaho: Isochron/West, no. 16, p. 11-12. [K-Ar]

200. McMannis, W. J., 1955, Geology of the Bridger Range, Montana: Geological Society of America Bulletin, v. 66 , no. 11 , p. $1385-1430$.

*201. McMannis, W. J., and Chadwick, R. A. 1964, Geology of the Garnet Mountain quadrangle, Gallatin County, Montana: Montana Bureau of Mines and Geology Bulletin 43, 47 p. [C]

**202. Meen, J. K., and Eggler, D. H., 1987, Petrology and geochemistry of the Cretaceous Independence volcanic suite, Absaroka Mountains, Montana-Clues to the composition of the Archean sub-Montanan mantle: Geological Society of America Bulletin, v. 98, no. 2, p. 238-247. [C]

*203. Meen, J. K., Eggler, D. H., and McCallum, M. E., 1986, Proterozoic granulite xenoliths from Ming Bar diatreme, Montana: Geological Society of America Abstracts with Programs, v. 18, no. 6, p. 692. [C]

204. Mertie, J. B., Jr., Fischer, R. P., and Hobbs, S. W., 1951, Geology of the Canyon Ferry quadrangle, Montana: U.S. Geological Survey Bulletin 972, 97 p.

205. M'Gonigle, J. W., 1965, Structure of the Maiden Peak area, Montana-Idaho: Unpublished Ph.D. dissertation, The Pennsylvania State University, University Park, $146 \mathrm{p}$.

*206. M'Gonigle, J. W., and Dalrymple, G. B., 1992, Written communication. [Ar-Ar]

207. M'Gonigle, J. W., Kirschbaum, M. A., and Weaver, J. N., 1991, Geologic map of the Hansen Ranch quadrangle, Beaverhead County, southwest Montana: U.S. Geological Survey Geologic Quadrangle Map GQ-1704.

208. Miller, F. K., 1989, Oral communication.

**209. Miller, F. K., and Engels, J. C., 1975, Distribution and trends of discordant ages of the plutonic rocks of northeastern Washington and northern Idaho: Geological Society of America Bulletin, v. 86, no. 4, p. 517-5़28. [K-Ar] 
**210. Miller, R. N., 1973, Production history of the Butte district and geologic function, past and present: Society of Economic Geologists Guidebook, Butte Field Meeting (Aug. 18-21), p. F1-F10. [K-Ar]

**211. Mitchell, R. H., and Bergman, S. C., 1991, Petrology of lamproites: New York, Plenum Press, 447 p. [K-Ar]

**212. Mitchell, R. H., Platt, R. G., and Downey, M., 1987, Petrology of lamproites from Smoky Butte, Montana: Journal of Petrology, v. 28, no. 4, p. 645-677. [C]

213. Mitchell, V. E., and Bennett, E. H., 1979a, Geologic map of the Driggs quadrangle, Idaho: Idaho Bureau of Mines and Geology Geologic Map Series, scale 1:250,000.

214. _ 1979b, Geologic map of the Elk City quadrangle, Idaho: Idaho Bureau of Mines and Geology Geologic Map Series, scale 1:250,000.

**215. Mudge, M. R., 1972, Structural geology of the Sun River Canyon and adjacent areas, northwestern Montana: U.S. Geological Survey Professional Paper 663-B, 52 p. [K-Ar]

216. Mudge, M. R., and Earhart, R. L., 1983, Bedrock geologic map of part of the northern Disturbed Belt, Lewis and Clark, Teton, Pondera, Glacier, Flathead, Cascade, and Powell Counties, Montana: U.S. Geological Survey Miscellaneous Investigations Series Map I-1375.

217. Mudge, M. R., Earhart, R. L., Whipple, J. W., and Harrison, J. E., 1982, Geologic and structure map of the Choteau $1^{\circ} \times 2^{\circ}$ quadrangle, western Montana: U.S. Geological Survey Miscellaneous Investigations Series Map I-1300.

**218. Mukherjee, N. S., 1968, Geology and mineral deposits of the Galena-Gilt Edge area, northern Black Hills, South Dakota: Unpublished Ph.D. dissertation, Colorado School of Mines, Golden, 288 p. [K-Ar]

219. Myers, P. E., 1982, Geology of the Harpster area, Idaho County, Idaho: Idaho Bureau of Mines and Geology Bulletin 25, $46 \mathrm{p}$.

220. Myers, W. B., 1952, Geology and mineral deposits of the northwest quarter Willis quadrangle and adjacent Brown's Lake area, Beaverhead County, Montana: U.S. Geological Survey Open-File Report, 46 p.

221. Nelson, W. H., 1963, Geology of the Duck Creek Pass quadrangle, Montana: U.S. Geological Survey Bulletin $1121 \neg \mathrm{J}, 56 \mathrm{p}$.

**222. Nelson, W. H., and Pierce, W. G., 1968, Wapiti Formation and Trout Peak Trachyandesite, northwestern Wyoming: U.S. Geological Survey Bulletin 1254-H, 11 p. [K-Ar; C]

*223. Nelson, W. H., and Ross, C. P., 1968, Geology of part of the Alder Creek mining district, Custer County, Idaho: U.S. Geological Survey Bulletin 1252-A, 30 p. [Pb- $\alpha$; C]

224. 1969, Geologic map of the Mackay quadrangle, south-central Idaho: U.S. Geological Survey Miscellaneous Geologic Investigations Map I-580.

225. Nelson, W. H., Prostka, H. J., and Williams, F. E., 1980, Geology and mineral resources of the North Absaroka Wilderness and vicinity, Park County, Wyoming, with sections on Mineralization of the Sunlight mining region and Geology and mineralization of the Cooke City mining district, by J. E. Elliott, and a section on
Aeromagnetic survey, by D. L. Peterson: U.S. Geological Survey Bulletin 1447, 101 p.

**226. Norman, M. D., and Leeman, W. P., 1990, Open-system magmatic evolution of andesites and basalts from the Salmon Creek volcanics, southwestern Idaho: Chemical Geology, v. 81, no. 3, p. 167-189. [C]

**227. Norman, M. D., and Mertzman, S. A., 1991, Petrogenesis of Challis volcanics from central and southwestern Idaho-Trace element and $\mathrm{Pb}$ isotopic evidence: Journal of Geophysical Research, v. 96, no. B8, p. 13,279-13,293. [C]

**228. Norman, M. D., McElwee, K. R., Duncan, R. A., and Leeman, W. P., 1986, K-Ar ages of Oligocene Salmon Creek volcanics, Owyhee Mountains, Idaho: Isochron/West, no. 46, p. 9-14. [K-Ar]

229. O'Brien, H. E., 1989, Petrogenesis of the mafic potassic rocks of the Highwood Mountains, Montana: Unpublished Ph.D. dissertation, University of Washington, Seattle, $295 \mathrm{p}$.

**230. O'Brien, H. E., Irving, A. J., and McCallum, I. S., 1991, Eocene potassic magmatism in the Highwood Mountains, Montana-Petrology, geochemistry, and tectonic implications: Journal of Geophysical Research, v. 96 , no. B8, p. 13,237-13,260. [C]

231. Page, N. J., Simons, F. S., and Dohrenwend, J. C., 1973a, Reconnaissance geologic map of the Mount Douglas quadrangle, Montana: U.S. Geological Survey Miscellaneous Field Studies Map MF-488.

232. _ 1973b, Reconnaissance geologic map of the Mount Wood quadrangle, Montana: U.S. Geological Survey Miscellaneous Field Studies Map MF-491.

**233. Pansze, A. J., 1972, K-Ar ages of plutonism, volcanism, and mineralization, Silver City, Owyhee County, Idaho: Isochron/West, no. 4, p. 1-4. [K-Ar]

**234. Parsons, W. H., 1939, Volcanic centers of the Sunlight area, Park County, Wyoming: Journal of Geology, v. 47 , no. 1 , p. $1-26$. [C]

235. -1942, Origin and structure of the Livingston igneous rocks, Montana: Geological Society of America Bulletin, v. 53 , no. 8, p. $1175-1186$.

236. Peale, A. C., 1896, Description of the Three Forks quadrangle [Montana]: U.S. Geological Survey Geologic Atlas, Folio 24, 5 p.

*237. Pearson, R. C., and Zen, E-an, 1985, Geologic map of the eastern Pioneer Mountains, Beaverhead County, Montana: U.S. Geological Survey Miscellaneous Field Studies Map MF-1806-A. [K- Ar]

**238. Pecora, W. T., 1942, Nepheline syenite pegmatites, Rocky Boy stock, Bearpaw Mountains, Montana: American Mineralogist, v. 27, no. 6, p. 397-424. [C]

**239. Pecora, W. T., Kerr, J. H., Brace, W. F., Stewart, D. B., Engstrom, D. B., and Dixon, H. R., 1957, Preliminary geologic map of the Warrick quadrangle, Bearpaw Mountains, Montana: U.S. Geological Survey Miscellaneous Geologic Investigations Map I- 237. [C]

240. Pekarek, A. H., 1977, The structural geology and igneous petrology of the Rattlesnake Hills, Wyoming: Wyoming Geological Association Earth Science Bulletin, v. 10 , no. 4 , p. $3-30$.

**241. Pekarek, A. H., Marvin, R. F., and Mehnert, H. H., 1974, $\mathrm{K}$-Ar ages of volcanics in the Rattlesnake Hills, central Wyoming: Geology, v. 2, no. 6, p. 283-285. [K-Ar] 
**242. Percious, J. K., Damon, P. E., and Olson, H. J., 1967, Radiometric dating of Idaho batholith porphyries, in Damon, P. E. and Associates, 1967, Correlation and chronology of ore deposits and volcanic rocks-Annual progress report C00-689-76, Contract AT(11-1)689, U.S. Atomic Energy Commission: Geochronology Laboratories, University of Arizona, Tucson, Appendix AX, 6 p. [K-Ar]

243. Pierce, W. G., 1978 , Geologic map of the Cody $1^{\circ} \times 2^{\circ}$ quadrangle, northwestern Wyoming: U.S. Geological Survey Miscellaneous Field Studies Map MF-963.

244. Pierce, W. G., and Hunt, C. B., 1937, Geology and mineral resources of north-central Choteau, western Hill, and eastern Liberty Counties, Montana: U.S. Geological Survey Bulletin 847- F, p. 225-264.

245. Pillmore, C. L., and Mapel, W. J., 1963, Geology of the Nefsy Divide quadrangle, Crook County, Wyoming: U.S. Geological Survey Bulletin 1121-E, 52 p.

**246. Pirsson, L. V., 1894, On some phonolitic rocks from the Black Hills: American Journal of Science, 3d ser., v. 47, p. 341-346. [C]

**247. 1900, Petrography of the igneous rocks of the Little Belt Mountains, Montana: U.S. Geological Survey 20 th Annual Report, Pt. 3, p. 463-581. [C]

**248. 1905, The petrology and geology of the igneous rocks of the Highwood Mountains, Montana: U.S. Geological Survey Bulletin 237, 208 p. [C]

249. Prostka, H. J., Antweiler, J. C., and Bieniewski, C. L., 1979, Mineral resources of the Du Noir Addition, Washakie Wilderness, Fremont County, Wyoming, with a section on Aeromagnetic survey, by $M$. D. Kleinkopf: U.S. Geological Survey Bulletin 1472, $35 \mathrm{p}$.

**250. Rasmussen, D. L., 1977, Geology and mammalian paleontology of the Oligocene-Miocene Cabbage Patch Formation, central-western Montana: Unpublished Ph.D. dissertation, University of Kansas, Lawrence, 794 p. [FT]

**251. Redden, J. A., Obradovich, J. D., Naeser, C. W., Zartman, R. E., and Norton, J. J., 1983, Early Tertiary age of pitchstone in the northern Black Hills, South Dakota: Science, v. 220, no. 4602, p. 1153-1154. [K-Ar, FT]

252. Reeves, Frank, 1927, Geology of the Cat Creek and Devils Basin oil fields and adjacent areas in Montana, in Contributions to economic geology, 1926: U.S. Geological Survey Bulletin 786-B, p. 39-95.

253. 1931, Geology of the Big Snowy Mountains, Montana, 1930: U.S. Geological Survey Professional Paper 165-D, p. 135-149.

**254. Reid, R. R., and Greenwood, W. R., 1968, Multiple deformation and associated progressive polymetamorphism in the Beltian rocks north of the Idaho batholith, Idaho, U.S.A.: International Geological Congress, 23d, Prague, 1968, Proceedings, v. 4, p. 75-87. [K-Ar]

255. Rember, W. C., and Bennett, E. H., 1979a, Geologic map of the Dubois quadrangle, Idaho: Idaho Bureau of Mines and Geology Geologic Map Series, scale $1: 250,000$.
256. - 1979b, Geologic map of the Hailey quadrangle, Idaho: Idaho Bureau of Mines and Geology Geologic Map Series, scale 1:250,000.

257. -1979c, Geologic map of the Hamilton quadrangle, Idaho: Idaho Bureau of Mines and Geology Geologic Map Series, scale 1:250,000.

258. 1979d, Geologic map of the Idaho Falls quadrangle, Idaho: Idaho Bureau of Mines and Geology Geologic Map Series, scale 1:250,000.

259. -1979e, Geologic map of the Pullman quadrangle, Idaho: Idaho Bureau of Mines and Geology Geologic Map Series, scale 1:250,000.

260. Reynolds, M. W., 1989, Written communication.

261. Rhodes, B. P., and Hyndman, D. W., 1984, Kinematics of mylonites in the Priest River "metamorphic core complex", northern Idaho and northeastern Washington: Canadian Journal of Earth Sciences, v. 21, no. 10, p. 1161-1170.

262. Richards, P. W., 1957, Geology of the area east and southeast of Livingston, Park County, Montana: U.S. Geological Survey Bulletin 1021-L, p. 385-438.

263. Roberts, A. E., 1972, Cretaceous and Early Tertiary depositional and tectonic history of the Livingston area, southwestern Montana: U.S. Geological Survey Professional Paper 526-C, 120 p.

264. Robinson, C. S., 1956, Geology of Devil's Tower National Monument, Wyoming: U.S. Geological Survey Bulletin 1021-I, p. 289-302.

265. Robinson, C. S., Mapel, W. J., and Bergendahl, M. H., 1964, Stratigraphy and structure of the northern and western flanks of the Black Hills uplift, Wyoming, Montana, and South Dakota: U.S. Geological Survey Professional Paper 404, 134 p.

266. Robinson, G. D., 1963, Geology of the Three Forks quadrangle, Montana, with sections on Petrography of igneous rocks, by H. F. Barnett: U.S. Geological Survey Professional Paper 370, 143 p.

267. Robinson, G. D., McCallum, M. E., and Hays, W. H., 1969, Geologic map of the Upper Holter Lake quadrangle, Lewis and Clark County, Montana: U.S. Geological Survey Geologic Quadrangle Map GQ-840.

268. Rohrer, W. L., 1965, Geologic map of the Adam Weiss Peak quadrangle, Hot Springs and Park counties, Wyoming: U.S. Geological Survey Geologic Quadrangle Map GQ-382.

269. _-1966, Geologic map of the Kisinger Lakes quadrangle, Fremont County, Wyoming: U.S. Geological Survey Geologic Quadrangle Map GQ-527.

**270. Rohrer, W. L., and Obradovich, J. D., 1969, Age and stratigraphic relations of the Tepee Trail and Wiggins Formations, northwestern Wyoming, in Geological Survey Research 1969: U.S. Geological Survey Professional Paper 650-B, p. B57- B61. [K-Ar]

271. Ross, C. P., 1950, Fluorspar prospects of Montana: U.S. Geological Survey Bulletin 955-E, p. 173-224.

272. - 1952, The eastern front of the Bitterroot Range, Montana: U.S. Geological Survey Bulletin 974-E, p. 135-175

273. 1963, Geology along U.S. Highway 93 in Idaho: Idaho Bureau of Mines and Geology Pamphlet No. 130,98 p. 
274. Ross, C. P., Andrews, D. A., and Witkind, I. J., 1955, Geologic map of Montana: U.S. Geological Survey, scale 1:500,000.

**275. Rostad, O. H., 1978, K-Ar dates for mineralization in the White Cloud-Cannivan porphyry molybdenum belt of Idaho and Montana-A discussion: Economic Geology, v. 73, no. 7, p. 1366- 1368. [K-Ar]

**276. Rouse, J. T., Hess, H. H., Foote, Freeman, Vhay, J. S., and Wilson, K. P., 1937, Petrology, structure, and relation to tectonics of porphyry intrusions in the Beartooth Mountains, Montana: Journal of Geology, v. 45 , no. 7 , p. $717-740$. [C]

*277. Rubel, D. N., 1971, Independence volcano-A major Eocene eruptive center, northern Absaroka volcanic province: Geological Society of America Bulletin, v. 82, no. 9, p. 2473- 2494. [C]

278. Ruppel, E. T., 1963, Geology of the Basin quadrangle, Jefferson, Lewis and Clark, and Powell Counties, Montana: U.S. Geological Survey Bulletin 1151, $121 \mathrm{p}$.

279. 1968, Geologic map of the Leadore quadrangle, Lemhi County, Idaho: U.S. Geological Survey Geologic Quadrangle Map GQ-733, 5p.

280. _- 1972, Geology of pre-Tertiary rocks in the northern part of Yellowstone National Park, Wyoming: U.S. Geological Survey Professional Paper 729-A, 66 p.

281. _-1980. Geologic map of the Patterson quadrangle, Lemhi County, Idaho: U.S. Geological Survey Geologic Quadrangle Map GQ-1529.

*282. Ruppel, E. T., and Lopez, D. A., 1981, Geologic map of the Gilmore quadrangle, Lemhi and Custer Counties, Idaho: U.S. Geological Survey Geologic Quadrangle Map GQ-1543. [K-Ar]

**283. _ 1988, Regional geology and mineral deposits in and near the central part of the Lemhi Range, Lemhi County, Idaho: U.S. Geological Survey Professional Paper 1480, 122 p. [K-Ar; C]

284. Ruppel, E. T., O'Neill, J. M., and Lopez, D. A., 1983, Preliminary geologic map of the Dillon $1^{\circ} \times 2^{\circ}$ quadrangle, Montana: U.S. Geological Survey Open-File Report 83-168.

**285. Russell, C. W., 1991, Gold mineralization in the Little Rocky Mountains, Phillips County, Montana, in Baker, D. W., and Berg, R. B., eds., Guidebook of the central Montana alkalic province: Montana Bureau of Mines and Geology Special Publication 100, p. 1-18. [C]

286. Sahinen, U. M., 1939, Geology and ore deposits of the Rochester and adjacent districts, Madison County, Montana: Montana Bureau of Mines and Geology Memoir no. 19, $53 \mathrm{p}$.

**287. Scambos, T. A., 1991, Isotopic and trace-element characteristics of the central Montana alkalic province kimberlite-aln[0014]ite suite, in Baker, D. W., and Berg, R. B., eds., Guideboook of the central Montana alkalic province: Montana Bureau of Mines and Geology Special Publication 100, p. 93-109. [C]

**288. Schassberger, H. T., 1972, A K-Ar age of a quartz monzonite dike in the Kirwin mining district, Park County, Wyoming: Isochron/West, no. 4, p. 31. [K-Ar]
289. Schmidt, R. G., 1977, Geologic map of the Craig quadrangle, Lewis and Clark and Cascade Counties, Montana: U.S. Geological Survey Geologic Quadrangle Map GQ-1411.

*290. 1978, Rocks and mineral resources of the Wolf Creek area, Lewis and Clark and Cascade Counties, Montana: U.S. Geological Survey Bulletin 1441, 91 p. [K-Ar; C]

**291. Schmidt, R. G., Pecora, W. T., and Hearn B. C., Jr., 1964, Geology of the Cleveland quadrangle, Bearpaw Mountains, Blaine County, Montana: U.S. Geological Survey Bulletin 1141-P, 26 p. [C]

**292. Schmidt. R. G., Pecora, W. T., Bryant, Bruce, and Ernst, W. G., 1961, Geology of the Lloyd quadrangle, Bearpaw Mountains, Blaine County, Montana: U.S. Geological Survey Bulletin 1081-E, p. 159-188. [C]

293. Scholten, Robert, and Ramspott, L. D., 1968, Tectonic mechanisms indicated by structural framework of central Beaverhead Range, Idaho-Montana: Geological Society of America Special Paper 104, 71 p.

294. Scholten, Robert, Keenmon, K. A., and Kupsch, W. O., 1955, Geology of the Lima region, southwestern Montana and adjacent Idaho: Geological Society of America Bulletin, v. 66, no. 4, p. 345-404.

*295. Sears, J. W., 1985, Middle Eocene tuff from the Missoula Basin, west-central Montana: Northwest Geology, v. 14, p. 33- 36. [K-Ar]

**296. Sheriff, S. D., and Gunderson, J. A., 1990, Age of the Adel Mountain volcanic field, west-central Montana: Isochron/West, no. 56, p. 21-23. [K-Ar]

*297. Simms, F. E., Jr., 1966, The igneous petrology, geochemistry, and structural geology of part of the northwestern Crazy Mountains, Montana: Unpublished Ph.D. dissertation, University of Cincinnati, Cincinnati, 339 p. [C]

298. Simons, F. S., Van Loenen, R. E., and Moore, S. L., 1985, Geologic map of the Gallatin Divide Roadless Area, Gallatin and Park Counties, Montana: U.S. Geological Survey Miscellaneous Field Studies Map MF-1569-B.

299. Simons, F. S., Armbrustmacher, T. J., Van Noy, R. M., Federspiel, F. E., and Ridenour, James, 1973, Mineral resources of the Beartooth Primitive Area and vicinity, Carbon, Park, Stillwater, and Sweet Grass Counties, Montana, and Park County, Wyoming, with a section on Interpretation of aeromagnetic data, by L. A. Anderson: U.S. Geological Survey Open-File Report, $207 \mathrm{p}$.

300. Sims, J. D., 1967, Geology and sedimentology of the Livingston Group, northern Crazy Mountians, Montana: Unpublished Ph.D. dissertation, Northwestern University, Evanston, $121 \mathrm{p}$.

*301. Skipp, Betty, 1984, Geologic map and cross sections of the Italian Peak and Italian Peak Middle Roadless areas, Beaverhead County, Montana, and Clark and Lemhi Counties, Idaho: U.S. Geological Survey Miscellaneous Field Studies Map MF-1601-B. [K-Ar]

**302. 1985, Contraction and extension faults in the southern Beaverhead Mountains, Idaho and Montana: U.S. Geological Survey Open-File Report $85-545,170$ p. [C] 
303. Skipp, Betty, and Peterson, A. D., 1965, Geologic map of the Maudlow quadrangle, southwestern Montana: U.S. Geological Survey Miscellaneous Geologic Investigations Map I-452.

*304. Smedes, H. W., 1966, Geology and igneous petrology of the northern Elkhorn Mountains, Jefferson and Broadwater Counties, Montana: U.S. Geological Survey Professional Paper 510, 116 p. [C]

305. 1967, Preliminary geologic map of the Butte South quadrangle, Montana: U.S. Geological Survey Open-File Report 67-203.

*306. Smedes, H. W., and Prostka, H. J., 1972, Stratigraphic framework of the Absaroka Volcanic Supergroup in the Yellowstone National Park region: U.S. Geological Survey Professional Paper 729-C, 33 p. [K-Ar]

**307. Smedes, H. W., and Thomas, H. H., 1965, Reassignment of the Lowland Creek volcanics to Eocene age: Journal of Geology, v. 73, no. 3, p. 508-510. [K-Ar]

308. Smedes, H. W., Klepper, M. R., and Tilling, R. I., 1988, Preliminary map of plutonic units of the Boulder batholith, southwestern Montana: U.S. Geological Survey Open-File Report OF-88-283.

309. Smedes, H. W., M'Gonigle, J. W., and Prostka, H. J., 1989, Geologic map of the Two Ocean Pass quadrangle, Yellowstone National Park and vicinity, Wyoming: U.S. Geological Survey Geologic Quadrangle Map GQ-1667.

*310. Sonderegger, J. L., Berg, R. B., and Mannick, M. L., 1980, A geologic map of the northern part of the Upper and Lower Red Rock Lake quadrangles, Beaverhead County, Montana: Montana Bureau of Mines and Geology Open-File Report 47, scale 1:62,500. [K-Ar]

*311. Soward, K. S., 1975a, Geologic map of the Hardy quadrangle, Cascade and Lewis and Clark Counties, Montana: U.S. Geological Survey Geologic Quadrangle Map GQ-1241. [C]

*312. 1975b, Geologic map of the Rocky Reef quadrangle, Cascade County, Montana: U.S. Geological Survey Geologic Quadrangle Map GQ-1240. [C]

*313. Staatz, M. H., 1972, Geology and description of the thorium-bearing veins, Lemhi Pass quadrangle, Idaho and Montana: U.S. Geological Survey Bulletin 1351, 94 p. [C]

314. -1973, Geologic map of the Goat Mountian quadrangle, Lemhi County, Idaho and Beaverhead County, Montana: U.S. Geological Survey Geologic Quadrangle Map GQ- 1097.

*315. 1983, Geology and description of thorium and rare-earth deposits in the southern Bear Lodge Mountains, northeastern Wyoming: U.S. Geological Survey Professional Paper 1049-D, 52 p. [K-Ar]

*316. Starmer, R. J., 1972, The distribution and geochemistry of the Big Timber dike swarm, Crazy Mountains, Montana: Unpublished Ph.D. dissertation, University of Cincinnati, Cincinnati, 90 p. [C]

**317. Stewart, D. B., Pecora, W. T., Engstrom, D. B., and Dixon, H. R., 1957, Preliminary geologic map of the Centennial Mountain quadrangle, Bearpaw Mountains, Montana: U.S. Geological Survey Miscellaneous Geologic Investigations Map I- 235. [C]
318. Stoll, W. C., and Armstrong, F. C., 1958, Optical calcite deposits in Park and Sweet Grass Counties, Montana: U.S. Geological Survey Bulletin 1042-M, p. 431-479.

319. Tanner, J. J., 1949, Geology of the Castle Mountain area, Montana: Unpublished Ph.D. dissertation, Princeton University, Princeton, $153 \mathrm{p}$.

*320. Tappe, John, 1966, The chemistry, petrology, and structure of the Big Timber igneous complex, Crazy Mountains, Montana: Unpublished Ph.D. dissertation, University of Cincinnati, Cincinnati, 134 p. [C]

*321. Toth, M. I., 1983, Reconnaissance geologic map of the Selway-Bitterroot Wilderness, Idaho County, Idaho, and Missoula and Ravalli Counties, Montana: U.S. Geological Survey Miscellaneous Field Studies Map MF- 1495-B. [Ar-Ar]

**322. Toth, M. I., and Stacey, J. S., 1992, Constraints on the formation of the Bitterroot Lobe of the Idaho Batholith, Idaho and Montana, from U-Pb zircon geochronology and feldspar $\mathrm{Pb}$ isotopic data: U.S. Geological Survey Bulletin 2008, 14 p. [Pb- U]

**323. Truscott, M. G., 1975, Petrology and geochemistry of igneous rocks of East Butte, Sweetgrass Hills, Montana: Unpublished Ph.D. dissertation, University of Saskatchewan, Saskatoon, 174 p. [K-Ar; C]

324. Tschanz, C. M., Kiilsgaard, T. H., and Seeland D. A., 1974, Geology of the eastern part of the Sawtooth National Recreation Area, Idaho in Mineral resources of the eastern part of the Sawtooth National Recreation Area, Custer and Blaine Counties, Idaho: U.S. Geological Survey Bulletin 1545-A, p. 17- 44.

**325. Tullis, E. L., 1940, The geology and petrography of Latah County, Idaho: Unpublished Ph.D. dissertation, University of Chicago, Chicago, 218 p. [C]

**326. Tureck-Schwartz, Kathy, and Hyndman, D. W., 1991, High-potassium igneous rocks of the Bearpaw Mountains, north-central Montana, in Baker, D. W., and Berg, R. B., eds., Guidebook of the central Montana alkalic province: Montana Bureau of Mines and Geology Special Publication 100, p. 111-120. [C]

*327. Tysdal, R. G., 1988, Geologic map of the northeast flank of the Blacktail Mountains, Beaverhead County, Montana: U.S. Geological Survey Miscellaneous Field Studies Map MF-2041. [K- Ar]

328. Tysdal, R. G., and Simons, F. S., 1985, Geologic map of the Madison Roadless Area, Gallatin and Madison Counties, Montana: U.S. Geological Survey Miscellaneous Field Studies Map MF-1605-B.

329. U.S. Geological Survey, 1972, Geologic map of Yellowstone National Park: U.S. Geological Survey Miscellaneous Geologic Investigations Map I-711.

330. Vine, J. D., 1956, Geology of the Stanford-Hobson area, central Montana: U.S. Geological Survey Bulletin 1027- J, p. 405-470.

331. Walker, G. W., and Robinson, P. T., 1990, Paleocene(?), Eocene, and Oligocene(?) rocks of the Blue Mountains region, in Walker, G. W., ed., Geology of the Blue Mountains region of Oregon, Idaho, and Washington: U.S. Geological Survey Professional Paper 1437, p. 13- 27.

332. Wallace, C. A., 1987, Generalized geologic map of the Butte $1^{\circ} \times 2^{\circ}$ quadrangle, Montana: U.S. Geological Survey Miscellaneous Field Studies Map MF-1925. 
333. Wallace, C. A., Schmidt, R. G., Lidke, D. J., Waters, M. R., Elliott, J. E., French, A. B., Whipple, J. W., Zarske, S. E., Blaskowski, M. J., Heise, B. A., Yeoman, R. A., O'Neill, J. M., Lopez, D. A., Robinson, G. D., and Klepper, M. R., 1986, Preliminary geologic map of the Butte $1^{\circ} \times 2^{\circ}$ quadrangle, western Montana: U.S. Geological Survey Open-File Report 86- 292, 14 p.

**334. Wallace, S. R., 1953, The petrology of the Judith Mountains, Fergus County, Montana: U.S. Geological Survey Open- File Report no. 214, 189 p. [C]

335. Wedow, Helmuth, Jr., Gaskill, D. L., Banister, D. P., and Pattee, E. C., 1975, Mineral resources of the Absaroka Primitive Area and vicinity, Park and Sweet Grass Counties, Montana: U.S. Geological Survey Bulletin 1391-B, $115 \mathrm{p}$.

336. Weed, W. H., 1899a, Description of the Fort Benton quadrangle [Montana]: U.S. Geological Survey Atlas, Folio 55, $7 \mathrm{p}$.

337. _ 1899b, Description of the Little Belt Mountains quadrangle [Montana]: U.S. Geological Survey Atlas, Folio 56,9 p.

338. _ 1900, Geology of the Little Belt Mountains, Montana, with notes on the mineral deposits of the Neihart, Barker, Yogo and other districts: U.S. Geological Survey 20th Annual Report, Pt. 3, p. 257-462.

**339. Weed, W. H., and Pirsson, L. V., 1895a, Highwood Mountains of Montana: Geological Society of America Bulletin, v. 6, p. 389-422. [C]

**340. 1895b, Igneous rocks of Yogo Peak, Montana: American Journal of Science, $3 d$ ser., v. 50, no. 300, p. 467-479. [C]

**341. 1896a, Geology of the Castle Mountain mining district, Montana: U.S. Geological Survey Bulletin 139,164 p. [C]

**342. 1896b, The Bearpaw Mountains of Montana: American Journal of Science, 4th ser., v. 1, no. 4, p. 283-301 and no. 5 , p. $351-362$; v. 2 , no. 8 , p. $136-$ 148 and no. 9 , p. 188-199. [C]

**343. 1896c, The geology of the Little Rocky Mountains: Journal of Geology, v. 4, no. 4, p. 399-428. [C]

344. Weis, P. L., Schmitt, L. J., Jr., and Tuchek, E. T., 1972, Mineral resources of the Salmon River Breaks Primitive Area, Idaho, with a section on Aeromagnetic survey, by W. E. Davis: U.S. Geological Survey Bulletin 1353-C, $91 \mathrm{p}$.

345. Weissenborn, A. E., and Weis, P. L., 1976, Geologic map of the Mount Spokane quadrangle, Spokane County, Washington, and Kootenai and Bonner Counties, Idaho: U.S. Geological Survey Geologic Quadrangle Map GQ-1336.

346. Wells, J. D., 1974, Geologic map of the Alberton quadrangle, Missoula, Sanders, and Mineral Counties, Montana: U.S. Geological Survey Geologic Quadrangle Map GQ-1157.

*347. Whipple, J. W., Mudge, M. R., and Earhart, R. L., 1987, Geologic map of the Rogers Pass area, Lewis and Clark County, Montana: U.S. Geological Survey Miscellaneous Investigations Series Map I-1642. [K-Ar]

**348. Williams, T. R., Harakal, J. E., and Armstrong, R. L., 1976, K-Ar dating of Eocene volcanic rocks near Drummond, Montana: Northwest Geology, v. 5, p. 21-24. [K-Ar]
349. Wilson, W. H., 1970, Geologic map of the Soapy Dale Peak quadrangle, Hot Springs County, Wyoming: Wyoming Geological Survey Map, scale 1:24,000.

350. Winters, A. S., 1968, Geology and ore deposits of the Castle Mountain mining district, Meagher County, Montana: Montana Bureau of Mines and Geology Bulletin 64, 64 p.

351. Witkind, I. J., 1969, Geology of the Teepee Creek quadrangle, Montana-Wyoming: U.S. Geological Survey Professional Paper 609, $101 \mathrm{p}$.

352. 1971, Geologic map of the Barker quadrangle, Judith Basin and Cascade Counties, Montana: U.S. Geological Survey Geologic Quadrangle Map GQ-898.

353. _-1972, Geologic map of the Henry's Lake quadrangle, Idaho and Montana: U.S. Geological Survey Miscellaneous Investigations Series Map I-781-A.

*354. _ 1973, lgneous rocks and related mineral deposits of the Barker quadrangle, Little Belt Mountains, Montana: U.S. Geological Survey Professional Paper 752, 58 p. [K-Ar, Rb-Sr]

355. - 1976, Geologic map of the southern part of the Upper Red Rock Lake quadrangle, southwestern Montana and adjacent Idaho: U.S. Geological Survey Miscellaneous Investigations Series Map I-943.

356. Wolff, J. E., 1938, Igneous rocks of the Crazy Mountains, Montana: Geological Society of America Bulletin, v. 49 , no. 10 , p. $1569-1626$.

**357. Woods, M. J., 1976, Fractionation and origin of the Highwood Mountain volcanics: Northwest Geology, v. 5, p. 1-9. [C]

358. Worl, R. G., Kiilsgaard, T. H., Bennett, E. H., Link, P. K., Lewis, R. S., Mitchell, V. E., Johnson, K. M., and Snyder, L. D., 1991, Geologic map of the Hailey $1^{\circ} \times$ $2^{\circ}$ quadrangle, Idaho: U.S. Geological Survey OpenFile Report 91-340.

359. Zen, E-An, 1988, Bedrock geology of the Vipond Park 15- minute, Stine Mountain 71/2-minute, and Maurice Mountain 71/2-minute quadrangles, Pioneer Mountains, Beaverhead County, Montana: U.S. Geological Survey Bulletin 1625, 49 p.

360. Zimmerman, E. A., 1966, Geology and ground-water resources of western and southern parts of Judith Basin, Montana: Montana Bureau of Mines and Geology Bulletin 50-A, 33 p.

Geologic map data only

* Geologic, geochronologic, and(or) geochemical data

** Geochronologic and(or) geochemical data only [K-Ar, potassium-argon; Ar-Ar, argon-argon; Rb-Sr, rubidiumstrontium; FT, fission track; $\mathrm{Pb}-\alpha$, lead-alpha; $\mathrm{Pb}-\mathrm{U}$, leaduranium; $\mathrm{Pb}$-Th- $\mathrm{U}$, lead-thorium-uranium; $\mathrm{C}$, chemistry]

\section{GENERAL REFERENCES}

[Not keyed to figure 2]

Clarke, F. W., 1900, Analyses of rocks from the laboratory of the United States Geological Survey 1880-1899: U.S. Geological Survey Bulletin 168, 308 p.

1904, Analyses of rocks from the laboratory of the United 
States Geological Survey 1880 to 1903: U.S. Geological Survey Bulletin 228, $375 \mathrm{p}$.

1915 , Analyses of rocks and minerals from the laboratory of the United States Geological Survey 1880 to 1914: U.S. Geological Survey Bulletin 591, 376 p.

Clarke, F. W., and Hillebrand, W. F., 1897, Analyses of rocks, with a chapter on Analytical methods, Laboratory of the United States Geological Survey, 1880-1896: U.S. Geological Survey Bulletin 148, $306 \mathrm{p}$.

Larsen, E. S., 1940, Petrographic province of central Montana: Geological Society of America Bulletin, v. 51, no. 6, p. 887948.

Larsen, E. S., and Buie, B. F., 1941, Igneous rocks of the Highwood Mountains, Montana. Part V. Contact metamorphism: Geological Society of America Bulletin, v. 52, no. 12, p. $1829-1840$.

Larsen, E. S., Hurlbut, C. S., Jr., Buie, B. F., and Burgess, C. H., 1941, Igneous rocks of the Highwood Mountians, Montana. Part VI. Mineralogy: Geological Society of America Bulletin, v. 52 , no. 12 , p. $1841-1856$.

Macdonald, R., Upton, B. G. J., Collerson, K. D., Hearn, B. C., Jr., and James, D., 1992, Potassic mafic lavas of the Bearpaw Mountains, Montana-Mineralogy, chemistry, and origin: Journal of Petrology, v. 33, pt. 2, p. 305-346.

Moye, F. J., Hackett, W. R., Blakely, J. D., and Snider, L. G., 1988, Regional geologic setting and volcanic stratigraphy of the Challis volcanic field, central Idaho, in Link, P. K., and
Hackett, W. R., eds., Guidebook to the geology of central and southern Idaho: Idaho Geological Survey Bulletin 27, p. 87-98.

Mutschler, F. E., Larson, E. E., and Bruce, R. M., 1987 (1988), Laramide and younger magmatism in Colorado-New petrologic and tectonic variations on old themes: Colorado School of Mines Quarterly, v. 82, no. 4, p. 1-47.

Pirsson, L. V., 1905, The petrographic province of central Montana: American Journal of Science, 4th ser., v. 20, no. 115, p. 35-49.

Sargent, K. A., and Jenness, J. E., 1983, Map showing outcrops of granitic rocks, ash-flow tuff, and laharic breccia, Basin and Range Province, Idaho: U.S. Geological Survey Water Resources Investigations Report 83-4117-C, $7 \mathrm{p}$.

Washington, H. S., 1917, Chemical analyses of igneous rocks published from 1884 to 1913 inclusive, with a critical discussion of the character and use of analyses: U.S. Geological Survey Professional Paper 9, $1201 \mathrm{p}$.

Weed, W. H., and Pirsson, L. V., 1895, On the rocks of the Sweet Grass Hills, Montana: American Journal of Science, $3 \mathrm{~d}$ ser., v. 50, no. 298 , p. 309-313.

1898 , Geology and mineral resources of the Judith Mountains of Montana: U.S. Geological Survey 18th Annual Report, Pt. 3, p. 437-616.

Wells, R. C., 1937, Analyses of rocks and minerals from the laboratory of the United States Geological Survey 1914-1936: U.S. Geological Survey Bulletin 878, 134 p. 
